\title{
TURKISH MANAGERS AS A PART OF THE TRANSNATIONAL CAPITALIST CLASS $^{1}$
}

\author{
Meltem Yilmaz Sener \\ Department of Sociology \\ University of Illinois at Urbana-Champaign \\ myilmaz2@uiuc.edu
}

\begin{abstract}
During the period after 1970s, capitalism has gone through a significant restructuring. This period has been primarily characterized by the process of globalization. Globalization has not emerged as the natural result of capitalism but it has been actively promoted and the appropriate conditions for the functioning of global capitalism have been created by certain actors. Many scholars argue that it is a newly emerging transnational capitalist class which transformed capitalism into a globalizing project. Although the members of this class are located in different parts of the world, they have a common interest in supporting globalization. They are aware of their common interests and they have a certain class consciousness. Moreover, their habits, tastes, and lifestyles are becoming increasingly similar. Considering these debates on transnational capitalist class, in a case study of the Turkish top managers working in the Istanbul branch of a multinational corporation, this paper looks at the lifestyle characteristics of this group of managers, comparing them with those aspects of the lifestyle of the transnational capitalist class that are indicated by the scholars. A second question that has been considered is to what extent these managers feel themselves as part of a transnational class that has common goals and interests. This study shows that for this group of managers the primary identification is with the people who have the same position with them, regardless of their country or corporation, not with their fellow nationals.
\end{abstract}

\section{INTRODUCTION}

For portraying the contemporary political, economic and social conditions of the world, no other concept has been as widely used as globalization. Although there are scholars who consider it as a myth (Hirst and Thompson 1996), globalization has been a key word for describing many of the changes that took place especially within the last twenty years. However, in many accounts, globalization as a term has been used without much clarification on how globalization as a process has emerged. Several scholars writing on globalization ignore the historical process behind its emergence and the active participation of several actors in the materialization of this

\footnotetext{
${ }^{1}$ An earlier version of this paper was presented at the 'Hegemonic Transitions and the State Conference' at Simon Fraser University in Vancouver, Canada. I would like to thank the audience in this conference, specifically Christopher Chase Dunn, and also Kenneth Barr for their useful comments. I also would like to thank Tim Liao and the graduate students who took his Publication Workshop in Spring 2007 at the University of Illinois at Urbana-Champaign for their comments on a different version of this paper.
} 
process. Moreover, they do not take into consideration the prevalent power dynamics and inequalities within and among countries. They represent globalization as an inevitable process that has occurred without the efforts of any parties and that homogenizes the whole world without creating any centers or dominant powers.

Many scholars agree with the idea that capitalism has gone through a significant restructuring since 1970s and this process of restructuring is called globalization (Burbach and Robinson 1999; Robinson and Harris 2000), neoliberal globalization (Nederveen-Pieterse 2004) or capitalist globalization (Sklair 2002a). However, globalization cannot be regarded as the natural result of capitalism; it has rather been created through "historically specific institutional forms". "Economic globalization is not an inevitable set of processes, but has instead been actively promoted by neoliberal theorists and politicians suspicious of state interference in civil society" (Faulks 1999:71). Globalization requires policies that establish the conditions that are claimed to be the results of the inevitable logic of global capital. Therefore, we can refer to "an active project of globalization" (McMichael 1996:31-32), a "globalist scale making project" (Tsing 2005:57) or a "transnational elite agenda" which aims to create the appropriate conditions for the functioning of global capitalism (Robinson 1996, 1997, 2004, 2005) taking place during the last three decades. We can consider globalization as a process which emerged through the active participation and efforts of certain groups and which mostly benefits those groups.

The recent debates on the emergence of a transnational capitalist class are really important within this context as they draw attention to the actors that turned globalization project into reality. Sklair argues that an emerging transnational class transformed capitalism into a globalizing project (Sklair 2001; see also Sklair 1996, 1997, 1998, 2002a, 2002b, 2005). He proposes a model of the global system based on transnational practices, which are divided into three spheres, namely economic, political and cultural-ideological. ${ }^{2}$ A major institution typifies each of these practices according to Sklair. The transnational corporation is the primary institution for economic, transnational capitalist class for political and culture-ideology of consumerism for cultural-ideological transnational practices. These three transform the world according to the global capitalist project. The members of the transnational capitalist class derive their power and authority from the corporations they own and control (Sklair 2001). Most of the TNCs are globalizing in important respects and the term global economy can be used to typify the economy dominated by these corporations. According to Sklair, transnational capitalist class is the major driver of globalizing practices and the leading force in the establishment of a global capitalist economy. This class is in the process of formation and it pursues people and resources of the world for its aim of increasing its private profit and accumulation. The transnational capitalist class can be identified with no particular country, but rather it is identified with the global capitalist system. This class consists of corporate executives, globalizing bureaucrats and politicians, globalizing professionals and consumerist elites. These capitalists in many different countries have more common interests with each other than they have with their non-capitalist citizens. The globalization of capital can only be adequately understood when the ownership and control of economic capital is considered together with ownership and control of other kinds of capital, which are political, organizational, cultural and knowledge capital. Here, the capitalist class is characterized by the ownership and control of major means of production, distribution and exchange through ownership and control of not only money but also other capitals (Sklair 2001).

Sklair lists five issues which explain why the transnational capitalist class is transnational or globalizing (Sklair 2005). First, the economic interests of the members of the transnational capitalist class are getting globally linked. Second, transnational capitalist class exercises its

\footnotetext{
${ }^{2}$ To these three spheres, Jerry Harris also adds a fourth one, which is the military industrial complex (Harris 2003).
} 


\section{JOURNAL OF WORLD-SYSTEMS RESEARCH}

economic control in the work place, political control in politics, and control of culture-ideology in everyday life through consumerist discourses and practices. Third, on economic, political and culture-ideology issues, members of transnational capitalist class have outward-oriented global perspectives. Fourth, members of this class have similar lifestyles, education, and consumption habits. And finally, they try to present an image of themselves as citizens of the world.

Although Sklair's studies can be regarded as major works on the formation of a transnational capitalist class, he is certainly not the only scholar who has claimed that a transnational capitalist class has emerged. Much earlier, in 1970s, Hymer talked about the emergence of an international capitalist class whose interests lie in the world economy as a whole system (Hymer 1979). Kees van der Pijl's work on international class formation (van der Pijl 1984, 1989, 1998), Stephen Gill's work about the "developing transnational capitalist class fraction" (Gill 1990) and Robert Cox's study on the emerging global class structure (Cox 1987) are other early studies that focus on class formation beyond the boundaries of nation states. Robinson and Harris, in their much debated study (see Arrighi 2001-2002; Mann 2001-2002; Moore 2001-2002; Robinson 2001-2002; van der Pijl 2001-2002; Went 2001-2002) argued that transnational capital has risen out of former national capitals and this process also had a transformative impact on capitalist classes which were previously national. "The leading capitalist strata worldwide are crystallizing into a Transnational Capitalist Class. Transnational class formation is therefore a key aspect of the globalization process" (Robinson and Harris 2000:14). Other important related studies are the works of Carroll and Fennema (2002) which provided evidence for the development of a transnational business community, Carroll and Carson (2003) which supported the claim that a "well-integrated global corporate elite" has formed, and van Apeldoorn $(2000,2005)$ which considered the formation of a European transnational capitalist class in addition to the emergence of a transnational capitalist class in general.

Although many of these studies make passing reference to the similarities in terms of lifestyle among the members of this emerging class, Sklair's book puts special emphasis on the lifestyle and ideological awareness as integral elements of the formation of the transnational capitalist class. Sklair argues that members of this class have similar lifestyles, similar patterns of education and consumption of luxury goods and services. "Integral to this process are exclusive clubs and restaurants, ultra-expensive resorts in all continents, private as opposed to mass forms of travel and entertainment, and, ominously, increasing residential segregation of the very rich secured by armed guards and electronic surveillance." (Sklair 2001:20-21). Members of this class also try to represent themselves as world citizens.

In a similar way, Cox also highlights the common culture among the members of this new class and their class consciousness. Regarding the dominant social groups, Cox lists them hierarchically as those who control big corporations operating on a world scale, those who control nation-based enterprises and industrial groups and locally based petty capitalists. Focusing on the first group, he states that this group has acquired a distinctive class consciousness and although they do not identify themselves as such, they can be called as a transnational managerial class. Although there are existing rivalries among these capitalists, still there is awareness in them of a common concern to maintain the system that makes it possible for this class to be dominant. Cox claims that various institutions such as the Trilateral Commission, OECD, IMF, and World Bank have articulated strategies for this concern. Also, business schools and international management training programs socialize new entrants to the values, lifestyles, language in the sense of shared concepts and symbols and business practices of the class. The culture of this class is specifically American and has been spread from a US base. This culture homogenizes the outlook and behavior of the members of the globally dominant group in certain ways that differentiate them from the cultures of national elite groups (Cox 1987).

Lastly, John Micklethwait and Adrian Wooldridge (2001), in their work A Future Perfect, also talk about the formation of a broadening class of people which share common lifestyle 
characteristics and name those people as cosmocrats. Globalization not only tightens world's economic links but also creates an increasingly conspicuous class of people who possess the ideas, connections and capitals necessary to be dominant in the international economy. Cosmocrats are the upper class people who have benefited from globalization. They make up the most meritocratic class the world has ever seen. These people share similar consumption habits no matter in which part of the world they live and they have cosmopolitan tastes.

Cosmopolitan in taste and usually Anglo-American in outlook, these are the people who attend business school weddings around the world, fill-up the business class lounges at international airports, provide the officer ranks of most of the world's companies and international institutions, and through their collective efforts, probably do more than anyone else to make the world seem smaller. These cosmocrats are members of a new ruling class- a much more meritocratic ruling class than we have ever seen before...but a ruling class nevertheless (Micklethwait and Wooldridge 2001:229).

Cosmocrats are defined by their attitudes and lifestyles as much as the amount of money they own. All of them are not Westerners but it is significant that even if some are not from the West, their values most of the times are. The cosmocratic values are the values of people who are constantly "on the move and on the make" rather than the ones who are comfortable with their traditions. These people have international loyalties. They usually have connections to and friends in many different countries so they have a continuous need for remaining in touch through voice mail, e-mail, and traveling. The common global aspirations of cosmocrats lead to common global habits. They have developed many ways of distinction to demonstrate their membership of the global elite. There is also a great emphasis on cosmopolitan consumerism (Micklethwait and Wooldridge 2001).

Three institutions are really crucial in binding these people together: business schools, big professional service firms, and the Internet. Business schools prefer selecting both their students and the faculty from many different countries, which is in line with their aims of creating and supporting the creation of environments that have diversity. The second type of institution, namely big professional service firm, includes law firms, accountancy firms, investment banks, and management consultancies. These institutions allow their members to have much more experience than regular business executives by making it possible for them to work in many countries and industries. They keep these people constantly moving, from one posting to another, working in different offices for short periods and going to specialized meetings. The last institution, the Internet, is a "cosmocratic gadget" (Micklethwait and Wooldridge 2001:237). It meets the two essential requirements of the cosmocrats, which are being connected and getting information.

The emerging theme in the discussions up to this point is the focus on the organization of the capitalist class on a world scale and their interests in supporting both the process and the rhetoric of globalization. The emerging transnational capitalist class is considered to be the major force in terms of globalizing practices and in the establishment of a global capitalist economy. This class is now going through the process of formation and it makes use of people and resources for increasing its profit and accumulation. The corporate executives of the multinational corporations form a significant part of this class. These people are aware of a common concern to maintain the system that makes it possible for their class to be dominant. Educational institutions like business schools are instrumental in creating a common culture, common lifestyles and shared concepts. The members of this class have homogeneous behaviors and similar consumption habits no matter where they live. Although their economic capital has been significant in their determination as members of a certain class, their social, cultural and symbolic 
capitals also need to be examined. They have common global habits and have developed many ways of distinction to distinguish themselves from other people of lower class backgrounds.

This paper focuses on the case of the upper level managers working in the İstanbul branch of a multinational consulting firm, considering these theoretical approaches on transnational capitalist class. Following Micklethwait and Wooldridge's (2001), Cox's (1987), and Sklair's (2001) emphasis on the cultural practices, lifestyles and ideological awareness of transnational executives as integral aspects of transnational capitalist class formation, I mostly look at the cultural practices, background characteristics, lifestyles, identifications and ideas of these Turkish managers. Working in a "peripheral" branch of a multinational corporation, which is located in a Third World city, these managers are not positioned at one of those centers from where global capitalism is managed (Carroll and Carson 2003). Moreover, there are scholars who argue that transnational class formation is weakest in the Third World (Robinson and Harris 2000). However, this does not necessarily mean that the managers in the Third World countries do not share similar lifestyle characteristics, ideologies, and global aspirations with those other managers who are positioned at the "centers". Besides, the formation of third-world globalists is an increasingly mentioned phenomenon (Harris 2005). With this in mind, I try to understand the kind of parallels between the backgrounds, lifestyles, and ideologies of these Turkish managers with those of their counterparts in the center. As this is not a comparative study that also has data about the managers in a First World country, I mostly consider the characteristics that are mentioned by the scholars writing on transnational capitalist class, such as frequently traveling to other countries, having business degrees, considering themselves as world citizens, and believing in their common interests as the members of a transnational class. Before proceeding further to elaborate on my case study, first I will explain how Turkey, as a Third World country, has been integrated into the process of globalization, how this integration took place as a process that is pursued by and benefits local and global capitalist groups, and how managers emerged as prominent figures in Turkish society through this integration.

\section{GLOBALIZATION OF THE THIRD WORLD AND "INTEGRATION" OF TURKEY TO THE GLOBAL SYSTEM}

In Western societies, until the 1970s, there was a period when inequality in terms of economic resources decreased due to industrialization and productivity, as wage incomes tended to grow more than capital incomes, and wage incomes on the lower occupational levels more than those on the higher ones. Due to the practices of the welfare state, more egalitarian social structures took place. However, beginning from 1970s, these circumstances started to change. The oil crisis, which took place in 1973, was a key event as it marked the beginning of a new stage of Western capitalism. Economic growth rates decreased and unemployment levels increased sharply. The governments restricted spending on social expenditures. The firms spread their operations on a global scale, capital became more mobile, international financial transactions increased, and markets were liberalized. There were also parallel changes in politics (Wilterdink 2000).

Through the influence of the developed countries and especially through the policies exerted by the International Monetary Fund and the World Bank, underdeveloped countries went through "the same paradigmatic shift" with the First World (Stewart and Berry 1999). The Structural Adjustment Programs (SAPs) applied through the directions of the IMF and the World Bank had the same objectives in all the countries. Among these are import liberalization, financial liberalization, privatization of public institutions, getting rid of the big and interventionist state, and reducing the social expenditures. Many underdeveloped countries started to adopt neo-liberal policies through the programs of the IMF and the World Bank, and to a large extent, they gave away their authorities on economic policies to these two institutions (Şenses 2001). The policies 
that were applied within the extent of the SAPs rested on unequal income distribution and they worsened the situation in terms of inequality in the countries where they were implemented. The declared aims of these programs were solving the debt problems of Third World Countries, keeping the exterior payments in balance, and maintaining growth (Bello 1999). However, they have not been successful in any of these. These programs played a significant role in the vicious circle of diminishing credit flows because of increasing debts, shrinking foreign capital investments, falling prices of primary goods of the Third World countries with vast increases in the prices of the industrial products. These brought huge decreases in growth rates, increasing poverty and inequality within and among the countries.

Turkey has been one of those countries which have been exposed to Structural Adjustment Programs and applied neoliberal policies especially since 1980s. The IMF and the World Bank had a significant influence in the implementation of the neoliberal policies in Turkey. Until 1980s, Turkey's economy was identified with import-substitution industrialization, which was mainly oriented to the domestic market. The instruments of economic policy, such as protectionism, state involvement, and regulated markets supported this orientation. During 1970s, crises emerged both in the economic and political areas in Turkey. The bourgeoisie was declaring openly their suggested solution. The same solution was also supported by the IMF, World Bank and OECD, which was the transformation of the economy. This transformation would include leaving the import-substitution strategy and adopting an export-oriented model. This would help Turkish industry to meet its own foreign currency requirements and would solve the problem of limited domestic market. This was not an easy thing to do and required serious efforts (Gülalp 1993).

Beginning from 1980s, the new orientation of export-led growth started to be imposed on Turkish economy. There was a widespread restructuring of the economic policy and neoliberalism became the new order of the period. This new order brought increasing foreign trade, interest rate liberalization, deregulation, privatization, decreases in state expenditures for social services, and a liberal foreign exchange regime instead of the state interventionism of the previous period (Balkan and Savran 2002). A powerful bureaucracy was not the precondition of development any more; it was an obstacle to the operation of the free market (Öncü and Gökçe 1991).

Domestic capitalist corporations in Turkey were pushing to be integrated to the increasingly internationalizing circuit of capital on the world scale. Ercan (2002) argues that internationalization of Turkish economy contributed to the advancement of big corporations at the expense of instability for the whole economy. There was an alliance between the domestic capitalist class and the IMF and the World Bank, both of which are institutions that represent the interests of the capitalists internationally (Ercan 2002). These two agencies played significant roles in the restructuring of Turkish economy through the $24^{\text {th }}$ January economic measures in 1980 (Balkan and Savran 2002; for neoliberal transformation of Turkish economy see also Başkaya 1991; Boratav 1991; Cizre-Sakallığlu 1991; Öngen 2003; Savran 2002; Tünay 2002; Yalman 2002).

The paradigmatic shift that was lived in the economic arena in Turkey during the 1980s also led to transformations in the social and cultural life. It is even possible to talk about the emergence of a new system of values in this period. With the passage to the free market economy, Turkey had intensified interactions with the external world. Goods that could only be bought from the black market or many imported goods that were regarded as luxury in the previous period, started to be sold in excessive amounts and acquiring these goods became a target for many people. Through the application of free market rules, the income levels of business people and managers started to increase rapidly and their levels of consumption also increased (Bali 2002). Yuppies (young urban professionals) emerged as the symbol of the period. They were the most educated and most successful members of a generation. Banking, finance and 
international marketing were prospering fields in the country and these people had the opportunity to earn huge amounts in these fields. Being a yuppie meant having a certain lifestyle and certain consumption habits, and their lifestyle has been influential on the expectations, consumption styles and ideology of the other segments of the society. They were the typical models of the valorized values of the period (Kozanoğlu 1993). The private lives of individuals, which remained untouched by the media in the previous periods, became objects of analysis and representation during 1980s. The lifestyles, for the first time, have been defined and classified. A private life industry emerged, creating its peculiar professions such as private life journalists and private life magazines (Gürbilek 1992).

After January 24 economic measures, integration of Turkish economy to the global market has been a priority. With this integration, trade, banking, and other service sectors became respected and prestigious. To be competitive in the new global economy, big family corporations started to employ middle and high level professional managers instead of employing family members (Bali 2002). The appropriate people for these sectors were the ones who could establish connections globally, communicate in foreign languages, and be competent. The graduates of top universities that instruct in English were very appropriate for these jobs. At the time, not only the company owners but also the professional managers had the opportunity to earn significant amounts of money in short periods. They represented the realization of the dreams of the majority of the people and became the symbol of success. Entrepreneurship and success were the most favorite values of the period (Kozanoğlu 1993). Being well-educated, bilingual people, they were demonstrated as the ones who knew the appropriate manners and ways of doing things. They were integrated to the Western World and could "speak the same language" with the Europeans. They were "world citizens" (Bali 2002).

By the removal of the limits on the financial operations and of the controls on foreign exchange transfers, credit cards and new banking services spread. Also, the advertising sector prospered significantly with the releasing of imports. The advertising sector mostly targeted the young, urban, well-educated managers who had high incomes. High quality clothes were advertised especially for these people as clothes made up an important part of their image. Also, expensive and luxurious restaurants and bars started to appear for serving the needs of these managers (Bali 2002).

Ankara was the city of bureaucracy and İstanbul has become the center of the new liberal and globalist orientation of the economy after 1980s. Multinational firms which did not have connections to Turkey in the previous periods started to make investments and establish branches in Turkey with the liberalization of Turkish economy. Most of these companies made their investments in İstanbul. The branches of foreign banks, exchange offices, leasing and insurance firms started business one after another. Following the foreign banks and firms, luxurious hotels were built in İstanbul. Later, the shopping malls and stores which targeted the people at high income levels appeared. The new shopping malls were no different from the ones in the other world cities. To the upscale European restaurants were added the Chinese, Japanese, Korean, Indian, Mexican ones. Entertainment sector has also prospered tremendously (Keyder 2000). All these newly emerging sectors and places have mainly served the professional people at high income levels.

Especially in İstanbul, new types of residences emerged for these elites. With the spreading of the discourse that İstanbul's social and cultural life were damaged with the newcomers (the migrants from rural areas), the city center was regarded as a place inappropriate for living a civilized life and new accommodation places were constructed outside the city center. "Bahçekentler" are the groups of villas that were built to be sold to high income groups. Their prices range between USD 250,000 and USD 1,000,000. They are outside the city centers and within natural surroundings. They provide the opportunity to the elites to live with people from similar backgrounds and to live apart from the lower classes (Öncï 1999). All these types of residences gave their inhabitants the opportunities to be away from the disorder of the city by 
creating spaces for personal activities. These places offered the people "a world of privileges": sports complexes, fitness centers, cinemas, restaurants, night clubs creating self-sufficient mini cities. The buyers of these residences bought not only houses but also certain lifestyles (Bali 1999). As Ahmet İnsel argues, these homogenized residences meet all kinds of social requirements of upper class people and make it possible for them to be isolated from the lower classes. This is the indication of an effort of social discrimination based on social class (İnsel 1999).

As Ayşe Öncü suggests (1999), high level managers of the firms that operate in the international markets have now been the part of a global business culture. Being a part of this culture does not only mean working through computers, speaking English, sitting in the VIP lounges, but also includes wearing similar clothes, reading certain magazines and newspapers, laughing at the same jokes, and having the same lifestyle (Öncï 1999).

At this point, it is important to clarify that when I refer to lifestyle, I mostly depend on Bourdieu's conceptualizations. Bourdieu (1984) states that in order to understand the lifestyle of an agent or agents, it is necessary to consider that there is homogeneity behind the various practices that appear diversified. The concept of habitus is introduced in order to clarify this homogeneity of practices. Habitus is "...the internalized form of class condition and of the conditionings it entails." (Bourdieu 1984:101). Although he does not completely exclude the classical differentiations between the classes, he thinks that it is not enough to regard the position in the relations of production, indicated by occupation, income level or even education, for defining a class.

Social class is not defined by a property...nor by a collection of properties...nor even by a chain of properties strung out from a fundamental property...in a relation of cause and effect, conditioner and conditioned, but by the structure of relations between all the pertinent properties which gives its specific value to each of them and to the effects they exert on practices (Bourdieu 1984:106).

Individuals who have similar conditions, thus, have similar systems of dispositions, which create similar practices and similar common properties. The classes of different conditions are differentiated from one another mostly by the total volume of capital, which includes economic, social, cultural and symbolic capitals. However, this primary difference is associated by secondary differences, which create class fractions having different asset structures or in other words, having different distributions of their total capital among these types of capital (Bourdieu 1984). These conditions produce different habituses, the systems of dispositions, which are both "structured structures" and "structuring structures" as they produce practices (Bourdieu 1977:72). People who have the same positions also have the same habitus or vice versa. The dispositions possessed as a result of the position occupied also brings with it an adjustment to this position. Habitus is not only defined by "the capacity to produce classifiable practices and works" but also by "the capacity to differentiate and appreciate the practices and works". The space of lifestyles is formed by the relationship between these two capacities (Bourdieu 1984).

\section{THE CASE OF TURKISH MANAGERS IN A MULTINATIONAL CORPORATION}

In the light of these arguments, in my case study of high-level managers in the Turkish branch of a multinational corporation, I tried to portray the lifestyle characteristics of these managers, considering the lifestyle conceptualization of Bourdieu and tried to see to what extent they feel themselves as part of a transnational class. In 2004, I interviewed eleven managers from the three highest managerial levels of senior partner, partner and senior manager from the İstanbul branch of this multinational corporation. In order to obtain additional information, I contacted junior 
employees who were working in the corporation at the time. And lastly, I also used global and Turkish web sites of the corporation for supplemental data about the organization and employees of the corporation both in Turkey and also worldwide.

In my selection of this corporation for my study, the fact that it is the branch of a big multinational corporation has been influential. Both Sklair (2001) and Cox (1987) argue that the people who work as managers in multinational corporations in several countries form a significant part of the transnational capitalist class. Therefore, selecting this corporation seemed appropriate for the purposes of my research. This corporation gives services of business consulting to public and private clients. It has its offices in 768 cities in 139 countries and has more than 120,000 people working in these offices. The corporation describes itself as a "truly global firm" and a "worldwide network of firms" which are locally owned and locally managed as indicated in the global web site. There is a CEO (Chief Executive Officer), a leadership team, consisting of key operation leaders and region leaders, and a Global Board, which form the management of the global body. The CEO is from the US and all the key operation leaders are either from the US or Europe. Of the 19 members of the Global Board one member is from Hong Kong, one from Sao Paulo and one from South Africa. The rest are from the US, Canada or Europe. To the identification of the firm itself as a network, it should be added that this is a network with some centers being more dominant in the management of the network, these centers being in the Western world.

Turkish branch of the corporation consists of four offices, two in İstanbul, one in Ankara and one in İzmir, with more than 550 professional staff. The professionals working in the firm are promoted on the basis of merit and performance. Although, in the past, there were people who had been directly employed to the upper levels of the organization from the public sector, usually the practice is that people become managers and even partners through being promoted in the organization. Becoming a partner in the corporation means acquiring the shares of the corporation and having important managerial responsibilities. The two senior partners have more shares and more managerial control within the corporation compared to other partners, and they represent the Turkish branch in the global organization.

For looking at their lifestyle, I took into account four capitals which are economic, cultural, social, and symbolic capitals, in line with Bourdieu's model. Following Bourdieu (1984), I took occupation, which is a variable that I know for the whole group, as the main determinant of economic capital. As I learned the income level for each managerial level through my contacts with junior level employees, this information has been sufficient for me to a large extent for positioning them in terms of economic capital. The income level for senior managers is around USD 100,000, for partners USD 200,000, and for senior partners around USD 500,000. Taking into consideration their occupational positions and income levels, I observed that these managers can be positioned at the upper class in terms of economic capital, as they get high salaries, own houses in wealthy districts of İstanbul, and have luxurious cars.

For cultural capital, first, I asked the managers the schools from which they graduated, beginning from primary school, as I wanted to see whether they went to private or public schools. All the managers I talked to graduated from public primary schools and most of them also graduated from public high schools. All of them got their undergraduate degrees from managerial and administrative areas (business administration, economics, and public administration) from the top public universities of Turkey (Bogazici University, Middle East Technical University, Ankara University, and İstanbul University). Additionally, three of them got their master's degrees from the universities in the US and one from a Turkish university, all in business related areas. The parents of most of these managers did not have high education. Although they are the children of relatively less educated families and they had their previous education in ordinary public schools, they achieved to be accepted to the top universities of Turkey. These facts support the argument that top level managers are meritocrats. They are not coming from well-educated, wealthy families and their cultural capital is not supported by their families' cultural, and in many cases 
economic, capital. However, we can talk about a reinforcement of their cultural capital by their spouses' education. The spouses of all the managers also graduated from the top universities. These managers are aware of the importance of cultural capital gained through education and they provide their children education in well-known private schools; all the managers who have children old enough to go to school send their children to famous private schools for education.

Competence in a foreign language is also an important part of cultural capital. All the managers are fluent in English. Half of them speak a second and two speak a third language. I observed that in addition to knowing English, they are very much used to using words in English in their daily conversations in Turkish. During interviews they used words in English extensively. Not only the technical terms and names of positions and titles, but also ordinary words were used in English. They also use the Internet extensively both for work purposes and also for personal communication with people from Turkey and abroad. In Bourdieu's (1984) scheme, activities like reading books, newspapers and magazines, and taste of music are also indicators of cultural capital. In terms of the kinds of books they read, we see that all of them read books about economy, their sector, and work-related issues in general. All the managers I interviewed also read at least two newspapers daily. There are ones who stated that they read five magazines in a day especially during weekends. Dünya, which is a newspaper on economy, is delivered to all the managers in the corporation and they stated that they read Dünya everyday. About magazine reading, all the managers stated that they read magazines about their sector. Also, six of the managers read foreign magazines like Newsweek, Time, and the Economist. There are also ones who read magazines about decoration, automobiles, and travel. These magazines also give clues about their symbolic capital, pointing out to the areas in which they try to create distinction. Home decoration is one of those areas that upper classes distinguish themselves from the lower classes. Automobiles are also one of the most valued prestige items. And lastly, traveling especially to different countries is a significant part of upper class lifestyle. Therefore, the magazines they read give ideas about their not only cultural but also symbolic capital by demonstrating that they have an interest in those areas which are mostly accessible to the upper classes.

When asked about their preferences in music, most of the managers named classical music as their first choice. Bourdieu (1984), while talking about legitimate taste, which belongs to the upper class, puts classical music within the category of legitimate taste; classical music is mainly the music of the upper class. This argument seems to be supported in my case. The other kinds of music listed by the managers are jazz, new age, and alternative rock by younger managers, and Turkish classical music (Türk Sanat Müziği) by older managers. Although not asked about the kind of music they are not fond of, two of the managers told that they never listen to Turkish Volk Music (Türk Halk Müziği) and also none of the managers mentioned this kind of music among the ones they listen to. This may be interpreted as their wish to distance their tastes from the tastes of the masses. As Bourdieu states, while considering good and bad tastes, things are classified as "distinguished" and "vulgar". It can be argued that classical music is the distinguished and Turkish Volk music is the vulgar one in terms of their music taste.

Regarding their social capital, I tried to understand their connections to powerful people from different fields. They have relationships and acquaintances with influential people not only from the field of business but also from the fields of politics, arts and media. Moreover, all of them have memberships in at least two associations, NGOs or clubs. They are mostly the members of occupational groups, alumni organizations of their universities and other organizations promoting international business and trade. Their membership in these organizations not only demonstrates their social capital but also gives an idea about their motivation and interest in supporting foreign investment in Turkey and the efforts of Turkish business circles to be integrated to the global business community.

Bourdieu (1984) uses the term symbolic capital for referring to the forms other capitals take when they are perceived. Regarding symbolic capital, managers I interviewed create 
distinction from the lower classes through type and district of their residences and the decoration of these houses, brands of their cars, restaurants and shopping malls they go to, the types of sports they deal with and memberships in big sports centers, the places from which they buy their clothes, the brands of these clothes and of the other goods they use, the places they go and stay in their holidays, going to foreign countries, and staying at luxurious hotels.

All of the managers live in the wealthier districts of İstanbul, such as Etiler, Nişantaş1, Ataköy, Arnavutköy, etc. Some of them live in special types of residences consisting of villas and containing recreational facilities. These are self-sufficient mini cities including sport complexes, fitness centers, cinemas, restaurants, etc. and they are far from the city center. Living in these special-type, luxurious, segregated residences forms a crucial part of the symbolic capital of these upper level managers, distinguishing them significantly from the lower classes. The decoration of the house is an important indicator of one's distinguished taste and a crucial way to show that taste to the others. Most of the managers used the services of professionals for decorating their houses. They have prestige items such as antique goods and paintings in their houses. Cars are another important signifier of status and a significant part of symbolic capital. The corporation provides a car to all senior managers, partners and senior partners. This car is not provided temporarily but becomes their property. There is not a standard car that is given to the managers; the corporation offers a certain amount of money for the car but the managers can give an additional amount and buy different brands of cars. All the managers that I interviewed own expensive and luxurious cars.

The data about the managers' experience abroad combined with the data about their educational experiences in foreign countries give us important insights about their access to foreign countries. Most of them stayed in foreign countries at least for one year either for work or for education. When combined with the data about frequent visits to foreign countries, we see that it is easy for these people to transcend the borders of their nation states. They are fluent in English and some of them also in other languages which are factors that make it possible for them to communicate easily.

I read them some statements and asked which of these statements seems the most appropriate for them to identify themselves and the reason for that identification. The statements are: "I am primarily a Turk." "I am primarily a Muslim." "I am primarily European." "I am primarily Middle Eastern." "I am primarily a world citizen." Most of my interviewees regard themselves as world citizens. Remembering Leslie Sklair's (2001) argument that the members of the transnational capitalist class try to represent themselves as world citizens, I can argue that this proposition is confirmed for the managers in my case. They think that being a Turk is something that they did not choose, so it is not a meaningful identification for them. They state that national boundaries do not have much relevance any more and they do not have to define themselves with their nationality. Without pointing out the power inequalities in the world, they talk about the importance of morality and values of humanity. Following are the comments of the ones who regard themselves chiefly as world citizens:

I am primarily a world citizen. I cannot be a nationalist. I was born here by chance. It is the same about religion. It was not my choice. Defending Islam as I was born as a Muslim... If I was born as a Christian, I would defend Christianity. It doesn't have any meaning. It seems more meaningful to be a world citizen. I am primarily a human being.

I am a world citizen. The others put one in a box. This one does not; it regards everyone equal. I do not want to be put in a box.

Among them, being a world citizen seems the most meaningful to me. I do not know to which degree I am European or Asian. Being a world citizen... It is a 
more universal concept. I do not believe that national boundaries have much meaning any more. Anyway, every problem is rooted in religion or national boundaries. But I am locally a Turk. I did not choose it. I was born and have grown up in this culture. My mother and father are Turks.

I think I will define myself firstly as a world citizen. Values of humanity come before those other statements, those chauvinist things. Before them come the universal values and human conscience. But of course, I am all of them to a certain degree.

I am above all a world citizen. I do not have a tendency to discriminate anyone because of his/her race or nationality. Hence, I also do not want to be discriminated. I do not want to have any advantages or disadvantages because of being a Turk. I would like to be evaluated according to my talents. From this perspective, being a world citizen is more appropriate to me. This does not mean a denial of being a Turk. I state that I am a Turk in every setting. I am a world citizen and secondly, I am a Turk. But being a Muslim does not have a priority for me. Our being Muslim is only something we say. We do not even pray...

As observed in these statements, they regard world citizenship as a concept that is the opposite of nationalism or chauvinism. They regard world citizenship as something universal, a category that points out the values of humanity. They explain that the term regards everyone equal but they do not talk about whether or not the conditions of that equality exist. Although ethically one can argue that universal human values are above all important for him/her and that he/she is first and foremost a human being, in the real social, political and economic conditions and the power relations in the world, many people cannot be defined boundless of their national origins. Only for the people who can easily transcend borders and who do not have any visa difficulties, world citizenship or being a cosmopolitan, is something that can be supported (Vertovec and Cohen 2002). Also, the fact that their lifestyle is similar to someone in a first world country gives them the idea that they are world citizens. Their class position gives them the opportunities to travel to other parts of the world without experiencing the problems "ordinary Turks" experience in terms of financial or visa difficulties, to be together with foreigners in various occasions, and to speak the same language with them. These experiences lead them to think that they might be free from being identified with their national origins. They believe that they can transcend being a Turk and be recognized as a world citizen. They think that compared to other Turks, they have more commonalities in terms of lifestyles and attitudes with the foreigners who have the same position with them in other countries and they identify this bond as world citizenship. ${ }^{3}$

I think it will be correct to define myself as European. I think I am above the average education, income, and culture levels of Turkish people. I am European in this sense. I have the same cultural and economic opportunities that European people have... This is why I feel that I have the similar standards, culture and

\footnotetext{
${ }^{3}$ Although the discourse of world citizenship or cosmopolitanism is mostly used as a mechanism of class distinction by these Turkish managers, it is important to recognize the existence of another kind of cosmopolitan discourse in Turkey, which might be considered as a left cosmopolitanism. While the scholars do not necessarily use the term cosmopolitanism, it can be argued that this position is exemplified by the writings of scholars such as Fuat Keyman, Ahmet İnsel, Murat Belge, and Ayşe Kadığlu in the newspaper Radikal and its Sunday supplement Radikal 2, as well as elsewhere.
} 


\section{JOURNAL OF WORLD-SYSTEMS RESEARCH}

moral values with Europeans. I feel like a European. Being a world citizen... I cannot comprehend concretely what being a world citizen means. I do not believe that in the world we are living, people treat each other equally. I do not think that such a concept, such a thesis has accuracy. It does not have any practical applications. A world in which all people treat each other with tolerance regardless of their national origins does not exist. The reality of the world is not as such. It would be wonderful if it was. It would be wonderful to feel as a world citizen.

In this quote, we see that he is aware of the inequalities throughout the world. It is striking that he thinks that he has more commonalities with Europeans than his lower class fellow citizens. His lifestyle makes him feel similar to people in foreign countries. He recognizes inequalities between Turkish people and Europeans, positioning them at the two poles in terms of income, education and culture levels, Turkish people being at the low and Europeans at the high end. He acknowledges the existence of inequalities but this does not lead him to criticize or to question these inequalities. He rather positions himself at the powerful side because of the privileges his class position brings. On the other hand, as he recognizes that there is not a parallel universe devoid of power inequalities among nations, he does not accept the concept of world citizenship.

The managers who told that they are primarily Turkish think that Turkish culture is something that shaped them to a large extent. One manager who lived in Hungary for two years stated that before living there, he felt more European.

It is necessary to say that I am primarily a Turk. It doesn't make any sense to argue that you are European. You understand that when you live in Europe. While living in Turkey, you can feel European comparing yourself with other Turks. However, when you live abroad, you even miss Turkish simit. ${ }^{4}$ You understand that you are Turkish when you go abroad. Before living in Hungary if someone had asked me this question, I would have told that I am European or world citizen. But now I know, it is the most accurate to define myself as a Turk.

Still, as we can see in the following quotation, he believes that he does not have common issues with other Turks, especially if they are from different socio-economic backgrounds. Although he primarily defines himself as a Turk, he considers himself as different from other, especially lower class Turks in terms of education and background.

When I look around myself in Turkey, I observe that I am really different from the general mass. The education level in Turkey is very low. This is a significant factor that explains our difference. I am also different in terms of background because my mother's family has been living in İstanbul for more than five hundred years. My mother has a Greek origin so is a true resident of İstanbul... There are many people from Black Sea region in İstanbul now and we have become a minority in İstanbul.

Related to these comments, I asked two related questions to the managers. I asked whether they think that they have similar lifestyles with the people who have the same positions with them in the foreign countries and whether they have more commonalities with these people

\footnotetext{
${ }^{4}$ Simit is a circular bread which is covered with sesame seeds. It is a common food in Turkey and is usually sold by street vendors.
} 
or with Turks from different backgrounds. Nine out of these eleven people told that their lifestyle is similar to that of foreigners having slmilar positions, and about the second question, ten of them told that they have more similarities with these foreigners compared to Turks with different backgrounds. However, they argued that in terms of cultural habits, they share more with Turks. It is interesting that they regard lifestyle and culture as totally separate issues.

I do not think that we have a lower standard than the foreigners who are at the same position with us. As our country is more traditional, from many aspects we have a better life compared to them... Traditional means giving more importance to family and friendship... These are important things for me. I like having friendship and family ties and recognition. A top level manager in Turkey has a better recognition compared to an American manager. When you leave your work place, you still have a certain status outside your office in Turkey...Compared to a Turk, my lifestyle resembles more to that of a foreigner. We read more books and newspapers. The places we go, the clothes we wear, the issues we spend our money for are similar. But in terms of thoughts and feelings, we have more common things with Turks. Common cultural heritage... For instance, a foreigner does not like çĭg köfte..."5

It is noteworthy that, in terms of major life activities or parts of daily life, he finds himself similar to foreigners. He finds common aspects with other Turks in issues, such as being fond of çĭg köfte, which is not a major part of his life. This is in parallel with the manager who stated that when he lived in Hungary, he understood that above all he is Turkish and even missed Turkish simit.

With the people who are at the same levels in other countries, we have many common aspects in terms of lifestyle. But their income level is higher than ours and they have more free time.... However, still we earn tremendous amounts especially if we consider the average income level in Turkey. While I was in college, I wouldn't have believed if someone had told me that I would earn this much...Compared to other Turks, I have more in common with foreigners of my level. The difference between me and Hasan Bey, an ordinary Turk is increasing rapidly. Our lifestyle is similar to that of a European. Frequency of reading books, going on holidays, places we go, importance we give to the education of our children are similar.

In terms of lifestyle, we are not different from foreigners at our level. They try to provide their children education in good universities of the US, I also try to. They deal with their hobbies, I also do. They have houses, summer houses, cars and life insurance. I also have... The difference is that there is less uncertainty in their lives. Their countries are more stable...I do not think that they are happier than me but they live in more welfare than me...I can get along well with the foreigners at the same level with me. Our experiences, backgrounds, perspectives

\footnotetext{
${ }^{5}$ Çĭg köfte is another Turkish food which is made of raw meat that is treated with spices.
} 


\section{JOURNAL OF WORLD-SYSTEMS RESEARCH}

are close to each other. I would like to contact Turks from lower levels. It would make me glad to be a model for them, to give them advice for their children or for themselves. The foreign people do not need me but the people at lower levels in Turkey need me... But it is easier for me to communicate with foreign people who have similar positions.

In the second passage, it is easy to notice that the only way he can relate to other "lower level" Turks is as a role model. His position and lifestyle makes him think that he is someone who accomplished to reach the desires of the masses and who is taken as an example by others. The relation between him and the foreigners of his level is a relation of equals but he stands somewhere above the other Turks.

In terms of places we go, things we do, and our values, we share a lot with our colleagues abroad. Our preferences are similar. Even our jokes are similar. We speak the same language. There may be minor differences in terms of our hobbies. They frequently play golf there. We do not play golf that much... I cannot get along with, for example, uneducated Turks. I prefer my foreign colleagues. Thus, I do not blame Germans for their dislike of Turks in their country.

Here, we see a higher level of identification with foreigners. The difference he can see between himself and people from other countries can only be minor differences in their hobbies. And also, national ties do not work in any degree when the other part is an uneducated Turk. He can feel himself in alliance with Germans who complain about the presence of uneducated Turks in their country. Therefore, I claim that for these upper class people, the bonds of citizenship do not have much importance and relevance, especially if the people in question are uneducated, compared to bonds of class, which transcend the national borders for this upper class.

In our company 130,000 people work worldwide. This is a great number. If you add the families of these people to this number, it makes a million. Many countries in the world have less than a million citizens. Thus, corporate culture starts to be more important than the culture of countries. Our corporate culture, for example, is determined by our Code of Conduct. In that Code, we promise to respect human rights, to believe in democracy, not to make discrimination. Corporate citizenship is a citizenship that has a wider scope... Even if there is corporate citizenship, there is one issue that should not be ignored: cultural diversity. Corporations such as ours have been in the domination of Anglo Saxons. The only reason of it is language. English is their native language. A German manager may be replaced by an English manager who has less intelligence, charisma and talents because of this. This has been relevant thus far. In order to value cultural diversity, we are now developing a new project... If you make business in diverse countries, you have to be adapted to that diversity.

What is explained in this quotation demonstrates the replacement of fellow nationals with colleagues in the corporation. Corporations took the place of nation states, Code of Conduct the place of the constitution and corporate culture the place of national culture within this framework. Even the issue of cultural diversity is discussed in the context of the corporation.

In the past, I had seen some statistics. When they listed the institutions and states according to their budgets, the first seven-eight are states and then come corporations. Many countries come in the list after the corporations. This is also 
reflected in the corporate cultures. Being the citizen of a corporation such as General Motors, which comes after seven big countries in the list, outweighs being the citizen of a country which is at the end of the list. The world accepts this as such. If you go on a business trip to a foreign country as a Turk and only show your identity card and passport, you will wait for hours in the queue. However, if you have the card of Volvo for instance, they will treat you differently. The corporate identities that some corporations provide to their employees prevail over the identities of underdeveloped countries.

These managers, who are the citizens of Turkey, seem to be willing to be identified with their corporations rather than their national origins for they recognize that they will have more benefits being the citizen of their corporation, rather than being a Turkish citizen. Regarding the understanding of citizenship according to which citizens are bound up with the community to which they belong to, we can say that for these managers, that community is not the nation state any more, but their corporation.

The answers to the question of whether they have difficulties in having visas also demonstrate how their corporate identity and class level make them privileged, and how corporate identity comes to the fore compared to their national identity. When the managers or their families want to have a visa either for business purposes or holiday, the corporation provides the necessary documentation and deals with the visa procedures.

We have never experienced a difficulty in having a visa. I think our corporation has played a significant role in this respect. My wife went to the US and received a visa for tens years in a week. It has been so easy, as we received it by the help of the corporation. If we had applied as ordinary citizens, we would have probably experienced various difficulties.

Still, some of them complain about waiting in the queues.

We don't have a problem about getting a visa. But there are queues. For example, in the US, we have to wait in the queues. However, in countries such as Netherlands, we do not have any difficulties. We just walk by and do not even stop.... I personally did not have a problem but I hear that Turks may have a lot of problems. The ones with tourist passports...

His usage of the word "Turks" is noteworthy here. He does not say "other Turks", but "Turks". It gives an impression that he does not regard himself as a Turk. In the following quotation also, we observe the privileged status they attribute to themselves.

I do not like attending the seminars abroad. When I want to go with my wife, we have problems with her visa. They want bank account and deeds of real estate from a man such as me. I get irritated. So now I call our clients and tell them to come to Turkey instead of going to those countries. Even if they had given me million dollars, I would not have accepted to live in those countries. The fact that they behave as such, to even people like us irritate me.

What he presents as a problem is showing necessary documents for getting a visa. In the statement about their requirement of documents "from a man such as him", we see the attitude of someone who regards himself very important and who thinks that he should be recognized in other countries as well. Also, visa procedures are seen as a problem when they are applied to not only ordinary people but also privileged ones, like them. 


\section{JOURNAL OF WORLD-SYSTEMS RESEARCH}

In addition to commonness of lifestyles, nine of the managers think that, whether they are in the same corporation or a different one, they have common interests with the people who have the same positions with them throughout the world. This means that even if there is competition among the firms, the managers still think that they still have mutual benefits with the managers of these firms. What they understand from mutual interests are mostly occupational interests.

We certainly have mutual interests. In terms of our occupational responsibilities, we share a common fate. If our sector becomes more important, all of us reach a better standard of living... The world is globalizing. The bankruptcy of a similar firm in the US because of a scandal and the regulations of the American parliament affected us a lot... We are in the same boat.

We, as a business community, have common interests against the regulatory body. In the primary business environment, we are in competition with the other firms. But against regulations and public pressures, our interests are common. When our competitor went bankrupt because of a scandal, we weren't happy with it. It brought negative consequences much more than positive ones.

Our common interests... For example, the proliferation of transparency in our country is to the benefit of all of us. In competition, transparency, fairness, we have common interests. We are all people who have confidence and we all want to be in an environment of fair competition. We do not want nepotism or theft.

As especially apparent in the first two quotations, these Turkish managers feel themselves as a part of a global business community and they position themselves in alliance against the regulatory bodies and public. They think that they form a group which has mutual interests with the foreign firms and their managers, even if they are in competitor firms. These interests should be protected even though they are against the interests of the public.

Lastly, I will reflect on their ideas about globalization and Turkey's position within this process. In terms of what they understand from globalization and their attitudes towards this process, there are a variety of positions. Some of them accept globalization predominantly as a technology-driven process, some mainly as an economic, and others as a cultural process. There are the ones who assess it mainly as having positive and others as having negative consequences. However, there is one issue that all of them agree on: inevitability and irreversibility of this process.

Globalization is inevitable. Turkey as a country has already been a part of it. Nobody asked our decision or choice about it. We have already been a part. Globalization is in the process of evolving. As it develops, people will increasingly get closer to each other and cultural interaction will increase. Thus, it is not only an economic process... Economic globalization is also inevitable. It will be beneficial for the humanity. Life standards will increase, technology will spread. Everybody will be able to gain knowledge in all the areas. The welfare level will be equal for everybody at the end. But these will take place after very difficult times... But eventually, it will reach to an equilibrium... Today, certainly people are exploiting, oppressing and deceiving each other. But there is no way to prevent it. Struggling not to be oppressed or exploited will lead to isolation and breaking off your foreign relations. Iran tried to do it but could not achieve. Cuba also tried but will not be able to do it. 
There is recognition of the inequalities within and among the countries under current conditions. But he believes that these relations of inequality will change, giving way to an equilibrium in terms of social and economic relations. However, it is not clear how this transformation will take place from the current unjust condition to that of peace and justice. People and countries should not struggle for not being oppressed. The free market ideology is in operation here; it seems that an "invisible hand" will bring everything to equilibrium. According to him, integration of Turkish economy to the global economy is an inevitable process which nobody can control. Here, he ignores the historical developments that took place, and conscious decisions and efforts made for articulating Turkish economy to the global economy.

Globalization has to be realized. It is relevant for Turkey, for Indonesia, for any other country... There is no country-specific thing about it. As long as the capital moves throughout the world, we should be a part of it so that we can get as much share as possible from that capital. I don't think that it has been totally accomplished. In the following years, Turkey will increasingly be integrated to this process.

Globalization... Neither negative nor positive... It is inevitable. It has both useful and harmful effects. Globalization is a gray notion, neither white nor black. But it is inevitable... Globalization for me is the shift to the authority of the consumer from that of the producer. I think this is the most useful impact of globalization. A negative aspect is a disregard of the poor people, the people who do not contribute to production...

These managers present globalization as the only alternative in the period we live. What Turkey should do is to try to get the biggest share from the international capital. Globalization as an ideology is highly internalized and supported by these managers. Although they recognize the negative consequences of it, still they consider them as inevitable. As a positive effect, "authority of the consumer" is mentioned. The chances of the people who have money to select among a variety of goods may be a benefit for those people, while it is not for the others. Moreover, it is questionable to what extent we can name this as the authority of the consumer.

According to me, globalization is a fact. Whether you like it or not... In the periods when imperialism was a fact, nobody asked the people in the colonies whether they liked it or not. Globalization will eventually be realized in full. However, I don't know to which extent. The world will never be composed of only one nation state... Increases in communication and worldwide travel are the factors that brought the emergence of globalization... Turkey is somewhere in the middle of this process now. Anyway, we cannot consider being outside of it. It may only be possible through closing your borders and prohibiting everything, like Korea. The rest of the world is within this process.

I think globalization hasn't been completed yet. When you consider the most globalized firms in the world, still there is a national flag behind them... I think globalization both has positive and negative aspects. As a positive effect, it serves world peace. When multinational corporations dominate the world, nationalism and conflicts about land disappear. It serves world peace in this sense. But it prevents competition and creates more oppression. It is a world in which there is more oppression but also more peace... It is not possible for Turkey to be out of this economic process. When you are isolated, you have to accept living in conditions of poverty. You cannot be both proud and rich at the 


\section{JOURNAL OF WORLD-SYSTEMS RESEARCH}

same time. This is why I think that Turkey has to be in the process of globalization. I don't want Turkey to be a country like Iran. But Turkey hasn't completed the integration process yet. This is because its economy hasn't developed enough and it cannot attract an adequate amount of foreign investment. Compared to China or other countries, Turkey receives only a small amount of foreign investment.

Taking into consideration the statements of the managers, it is clear that they are aware of some of the negative consequences of the process of globalization. Although it will be a long quotation, I will cite here the words of a manager about globalization and its negative consequences.

I think globalization has two dimensions: economic dimension and social dimension. The economic dimension has been accomplished much more quickly. Liberal economy and its spreading all over the world... In terms of social dimension, it will be the spreading of democracy throughout the world. There is a problem when there is difference between them in terms of timing. For instance China; its economy is liberal but social system is not democracy. This is the most dangerous type of country for the world... We should consider globalization in two stages: the starting of it at 1989, with the collapse of Soviet Union and its first stage took place until 1998. The stage that took place until 1998 Seattle World Trade Organization Meeting was the stage of violent capitalism. In 1990, among the most developed economies, 8 were firms and 92 were countries. In 1998, it has been 48 firms and 52 countries. Firms grew faster. The difference between the rich and poor people, and the poverty level increased incredibly. Of the 6.5 billion people living in the world, 2 billion do not have access to clean water... This is a serious problem. People escape from their countries by ships. They take refuge in Spain by swimming from Morocco. Taking refuge by swimming means you cannot carry anything with you. You only want to leave.

After 1998, there has been a real eye-opening effect in Seattle. There have been big demonstrations and Bush could not go to the meeting from his hotel. After 1998, social responsibility started to come to the fore. The problems of the world cannot be solved by the states; there are firms larger than states. Therefore, now, the economic part should be reconciled and democracy should be spread. It is necessary to share the welfare and to form a social and liberal economy which takes into consideration the social values. Otherwise, it will not be sustainable. When Titanic was sinking, both the ones who were drinking champagne at the top of the ship and the poor Irish people at the bottom died. The situation of the world is going there... I am not trying to say that globalization will bring the end of the world. In fact, liberal economy has no substitute. Economy has to be liberal, people should be able to invest anywhere in the world. However, when profit maximization is targeted without considering the social responsibilities, this will bring serious problems.

This paragraph is really interesting in that it includes many elements of social science discourses and very much resembles some of the contemporary social science texts, mentioning poverty and the other problems globalization created. It can be argued that both businessmen and business literature have become familiar with the concept of social responsibility within the last decade. It may be regarded as a development compared to the stage of "violent capitalism" mentioned by my interviewee. However, we can say that this articulation never gives way to 
TURkish Managers as Part OF The Transnational Capitalist Class 138

pointing out the real causes of the problems, which are usually related to the system itself. Moreover, global capital strengthens its position by embracing some of the elements of the critical discourses and resistance without a radical transformation of the system.

\section{CONCLUSION}

In my study of the high level managers in the İstanbul branch of a multinational corporation, I observed that most of these managers regard themselves primarily as world citizens. Being a Turk or a Muslim may be things that have constructed them but they would like to be free from these identifications. They accept that they have similar lifestyles with top level managers in the other countries. Most of them find themselves closer to the foreigners at their levels compared to Turks from other socio-economic backgrounds, in terms of common characteristics or habits. They also think that they have common interests with the foreign managers, regardless of whether they work in the same corporation or in other competitor corporations. They mention their mutual benefits. These responses point out the corrosion of national citizenship ties in the perspective of these managers. Their primary identifications are with the people who have the same position with them, regardless of country or corporation, not with their fellow nationals. Although they have diverse positions about the content and consequences of globalization, all of them believe that it is an inevitable and irresistible process. Although they accept that Turkey has been included in this process with a subordinate status, still they think that it is impossible to remain out of this process. What Turkish people should do is to struggle for getting as much as possible from the transnational capital. Although they talk about the social problems experienced as a result of this process, they regard these negative consequences as inevitable and do not point out the root causes of them. What they suggest is to wait and see the good days that will come at last.

Regarding the question about the transnational capitalist class, I mainly considered their access to foreign countries and their opinions about such issues as globalization, Turkey's integration to this process, identification of themselves in terms of national belonging, world citizenship, corporate citizenship, and how they perceive their lifestyle compared to that of foreigners having the same position and to that of Turkish people from different classes. According to the statements of my interviewees, all of them go to foreign countries at least three to four times a year, some of them going a couple of times in a month. All of them go abroad both for business purposes and for holidays. Thus they have a high access to other countries. However, when they go abroad, they predominantly spend their time with their counterparts from work. Thus, going to other countries means strengthening their relationships with the people who are from different countries but who have the same class position, similar backgrounds and lifestyles with them. The lifestyle of the upper class which primarily rests on isolation from lower classes is also maintained when they go abroad.

According to the statements of my interviewees, most of them think that they have similar lifestyles with foreign people from the same class with them and they have more commonalities with these people compared to Turks from different social classes. They also believe that they have common interests with the people from other countries that have the same positions with them. This demonstrates the weakening of bonds that rest on being the citizens of a particular nation state, while the bonds resting on being the members of a transnational class strengthen.

Lastly, there is one significant question that I should ask: Do these managers, who work in a Third World country, have all the privileges that the managers who work in First World countries have? I think although they have privileged lifestyles as a result of their class position, still they are people from a Third World country and they experience the disadvantages this fact brings. Although it is easy for them to get visas, we should remember that they are still bound by visas when they want to go abroad. They are aware that showing the card of their corporation 
eases visa procedures for them. Without that, with an ordinary identity card and passport, they will experience many problems. Moreover, as some of the managers talked about, there is a hierarchy among the managers of the corporation worldwide and Anglo Saxons stay at the top of this hierarchy, having more privileges compared to other managers from different national origins. Being aware of the disadvantages they have because of their national origin, they try to emphasize their corporate identity instead of national identity. As they regard themselves in an upper position compared to other Turks and as they accept Turkish identity as creating problems for them, they prefer being a citizen of their corporation or being a world citizen. These two citizenships make it possible for them to identify with people who have higher living standards and privileged positions, instead of Turkish people, the lifestyles of whom they disparage.

\section{REFERENCES}

Arrighi, Giovanni. 2001-2002. "Global Capitalism and the Persistence of the North-South Divide." Science and Society 65(4):469-476.

Bali, Rıfat. 1999. "Çılgın Kalabalıktan Uzak..." Birikim Temmuz:35-46. . 2002. Tarz-ı Hayattan Lifestyle’a: Yeni Seçkinler, Yeni Mekanlar, Yeni Yaşamlar. İstanbul, Turkey: İletişim.

Balkan, Neşe and Sungur Savran. 2002. The Ravages of Neoliberalism: Economy, Society, and Gender in Turkey. New York: Nova Science Publishers.

Başkaya, Fikret. 1991. Paradigmanın Iflası: Resmi Ídeolojinin Eleştirisine Giriş. İstanbul, Turkey: Doz Yayınları.

Bello, Walden. 1999. Dark Victory: The United States, Structural Adjustment, and Global Poverty. Oakland, CA: Food First Books.

Boratav, Korkut. 1991. 1980’li Yıllarda Sosyal Sinıflar ve Bölüşüm. İstanbul, Turkey: Gerçek Yayınevi.

Bourdieu, Pierre. 1984. Distinction: A Social Critique of the Judgment of Taste. Cambridge, MA: Harvard University Press. . 1977. Outline of a Theory of Practice. Cambridge, UK: Cambridge University Press.

Burbach, Roger and William I. Robinson. 1999. "The Fin De Siecle Debate: Globalization as Epochal Shift." Science and Society 63(1):10-39.

Carroll, William K. and Colin Carson. 2003. "The Network of Global Corporations and Elite Policy Groups: A Structure for Transnational Capitalist Class Formation?" Global Networks 3(1):29-57.

Carroll, William K. and Meindert Fennema. 2002. "Is There a Transnational Business Community?” International Sociology 17(3):393-419.

Cizre-Sakallığlu, Ümit. 1991. "Labor: The Battered Community." Pp. 57-69 in Strong State and Economic Interest Groups: The Post 1980 Experience, edited by M. Heper. New York: Walter de Gruyter.

Cox, Robert W. 1987. Production, Power and World Order. New York: Columbia University Press.

Ercan, Fuat. 2002. "The Contradictory Continuity of the Turkish Capital Accumulation Process: A Critical Perspective on the Internationalization of the Turkish Economy." Pp. 21-37 in The Ravages of Neoliberalism: Economy, Society and Gender in Turkey, edited by N. Balkan. and S. Savran. New York: Nova Science Publishers Inc.

Faulks, Keith. 1999. Political Sociology: A Critical Introduction. Edinburgh, UK: Edinburgh University Press.

Gill, Stephen. 1990. American Hegemony and the Trilateral Commission. Cambridge, UK: Cambridge University Press.

Gülalp, Haldun. 1993. Kapitalizm, Sinıflar ve Devlet. İstanbul, Turkey: Belge Yayınları. 
Gürbilek, Nurdan. 1992. Vitrinde Yaşamak: 1980’lerin Kültürel İklimi. İstanbul, Turkey: Metis.

Harris, Jerry. 2003. "The Conflict for Power in Transnational Class Theory." Science and Society 67(3):329-339. . 2005. "To Be or Not To Be: The Nation-Centric World Order Under Globalization." Science and Society 69(3):329-340.

Hirst, Paul and Grahame Thompson. 1996. Globalization in Question. Cambridge, UK: Polity Press.

Hymer, Stephen H. 1979. The Multinational Corporation: A Radical Approach. Cambridge, UK: Cambridge University Press.

İnsel, Ahmet. 1999. "Yaşam Alanlarımıza Sahip Çıkmak." Birikim Temmuz: 23-25.

Keyder, Çağlar. 2000. İstanbul: Küresel ile Yerel Arasında. İstanbul, Turkey: Metis.

Kozanoğlu, Hayri. 1993. Yuppieler, Prensler ve Bizim Kuşak. İstanbul, Turkey: İletişim.

Mann, Michael. 2001-2002. "Globalization is (Among Other Things) Transnational, International, and American." Science and Society 65(4):464-469.

McMichael, Philip. 1996. "Globalization, Myths, and Realities." Rural Sociology 61(1):25-55.

Micklethwait, John and Adrian Wooldridge. 2001. A Future Perfect: The Challenge and Hidden Promise of Globalization. London, UK: Random House.

Moore, Jason W. 2001-2002. "Capital, Territory, and Hegemony over the Longue Duree." Science and Society 65(4):476-484.

Nederveen- Pieterse, Jan. 2004. Globalization or Empire? New York: Routledge.

Öncü, Ayşe. 1999. "İdealinizdeki Ev Mitolojisi Kültürel Sınırları Aşarak İstanbul'a Ulaştı." Birikim Temmuz: 26-34.

Öncü, Ayşe and Deniz Gökçe. 1991. "Macro-Politics of Deregulation and Micro-Politics of Banks" Pp. 99-117 in Strong State and Economic Interest Groups: The Post 1980 Experience, edited by M. Heper. New York: Walter de Gruyter.

Öngen, Tülin. 2003. "Yeni Liberal Dönüşüm Projesi ve Türkiye Deneyimi." Pp. 161-189 in Küresel Düzen: Birikim, Devlet ve Siniflar, edited by A. Köse, F. Şenses and E. Yeldan. İstanbul, Turkey: İletişim.

Robinson, William I. 1996. "Globalization: Nine Theses of Our Epoch." Race and Class 38(2):13-31.

. 1997. "A Case Study of Globalization Processes in the Third World: A Transnational Agenda in Nicaragua." Global Society 11(1):61-92. 2004. A Theory of Global Capitalism. Baltimore, MD: Johns Hopkins University Press.

Robinson, W.I. 2001-2002. "Global Capitalism and Nation-State-Centered Thinking- What We Don't See When We Do See Nation States: Response to Critics." Science and Society 65(4):500-508.

2005. "Global Capitalism: The New Transnationalism and the Folly of Conventional Thinking." Science and Society 69(3):316-328.

Robinson, W.I. and J. Harris. 2000. "Towards A Global Ruling Class? Globalization and the Transnational Capitalist Class." Science and Society 64(1):11-54.

Savran, Sungur. 2002. "The Legacy of the Twentieth Century." Pp. 1-20 in The Politics of Permanent Crisis: Class, Ideology and State in Turkey, edited by N. Balkan and S. Savran. New York: Nova Science Publishers Inc.

Şenses, Fikret. 2001. Küreselleşmenin Öteki Yüzü Yoksulluk. İstanbul, Turkey: İletişim.

Sklair, Leslie. 1996. "Conceptualizing and Researching the Transnational Capitalist Class in Australia." Journal of Sociology 32(2):1-19.

1997. "Social Movements for Global Capitalism: The Transnational Capitalist Class in Action." Review of International Political Economy 4(3):514-538.

1998. "The Transnational Capitalist Class and Global Capitalism: The Case of the Tobacco Industry." Political Power and Social Theory 12:3-43. . 2001. The Transnational Capitalist Class. Oxford, UK: Blackwell. 
. 2002a. "Democracy and the Transnational Capitalist Class." Annals of the American Academy of Political and Social Science 581:144-157.

. 2002b. "The Transnational Capitalist Class and Global Politics: Deconstructing the Corporate-State Connection.” International Political Science Review 23(2):159-174.

. 2005. "The Transnational Capitalist Class and Contemporary Architecture in Globalizing Cities." International Journal of Urban and Regional Research 29(3):485-500.

Stewart, Frances and Albert Berry. 1999. "Globalization, Liberalization and Inequality: Expectations and Experience." Pp.150-186 in Inequality, Globalization and World Politics, edited by A. Hurrell and N. Woods. Oxford, UK: Oxford University Press.

Tsing, Anna. 2005. Friction: An Ethnography of Global Connection. Princeton, NJ: Princeton University Press.

Tünay, Mahmut. 2002. “Türk Yeni Sağının Hegemonya Girişimi.” Praksis (5):177-197.

van Apeldoorn, Bastian. 2000. "Transnational Class Agency and European Governance: The Case of the European Roundtable of Industrialists." New Political Economy 5(2):157181.

2005. “Transnational Business: Power Structures in Europe's Political Economy.” Pp.83106 in Transnational European Union: Towards a Political Space, edited by W. Kaiser and P Starie. New York: Routledge.

van der Pijl, Kees. 1984. The Making of an Atlantic Ruling Class. London, UK: Verso. . 1989. "The International Level." Pp. 237-266 in The Capitalist Class: An International Study, edited by T. Bottomore and R.J. Brym. New York: New York University Press. . 1998. Transnational Classes and International Relations. London, UK: Routledge. . 2001-2002. "Globalization or Class Society in Transition?" Science and Society 65(4):492-500.

Vertovec, Steven and Robin Cohen. 2002. "Introduction: Conceiving Cosmopolitanism." Pp. 122 in Conceiving Cosmopolitanism: Theory, Context and Practice, edited by S. Vertovec and R. Cohen. Oxford, UK: Oxford University Press.

Went, Robert. 2001-2002. "Globalization: Towards a Transnational State? A Skeptical Note." Science and Society 65(4):484-491.

Wilterdink, Nico. 2000. "The Internationalization of Capital and Trends in Income Inequality in Western Societies." Pp. 187-200 in The Ends of Globalization: Bringing Society Back In, edited by D. Kalb et al. New York: Rowman and Littlefield Publishers.

Yalman, Galip. 2002. "The Turkish State and Bourgeoisie in Historical Perspective: A Relativist Paradigm or a Panoply of Hegemonic Strategies?" Pp. 21-54 in The Politics of Permanent Crisis: Class, Ideology and State in Turkey, edited by N. Balkan and S. Savran. New York: Nova Science Publishers Inc. 